\title{
Impact of Holuhraun volcano aerosols on clouds in cloud-system resolving simulations
}

\author{
Mahnoosh Haghighatnasab ${ }^{1}$, Jan Kretzschmar ${ }^{1}$, Karoline Block ${ }^{1}$, and Johannes Quaas ${ }^{1}$ \\ ${ }^{1}$ Institute for Meteorology, Universität Leipzig, Leipzig, Germany
}

Correspondence: Mahnoosh Haghighatnasab (Mahnoosh.Haghighatnasab@uni-leipzig.de)

\begin{abstract}
Increased anthropogenic aerosols result in an enhancement in cloud droplet number concentration $\left(N_{\mathrm{d}}\right)$, which consequently modifies the cloud and precipitation process. It is unclear how exactly cloud liquid water path (LWP) and cloud fraction respond to aerosol perturbations. A volcanic eruption may help to better understand and quantify the cloud response to external perturbations, with a focus on the short-term cloud adjustments. The goal of the present study is to understand and

5 quantify the response of clouds to a selected volcanic eruption and to thereby advance the fundamental understanding of the cloud response to external forcing. In this study we used the ICON (ICOsahedral Non-hydrostatic) model in its numerical weather prediction setup at a cloud-system-resolving resolution of $2.5 \mathrm{~km}$ horizontally, to simulate the region around the Holuhraun volcano for one week (1 - 7 September 2014). A pair of simulations, with and without the volcanic aerosol plume, allowed us to assess the simulated effective radiative forcing and its mechanisms, as well as its impact on adjustments of LWP and cloud fraction to the perturbations of $N_{\mathrm{d}}$. In comparison to MODIS (Moderate Resolution Imaging Spectroradiometer) satellite retrievals, a clear enhancement of $N_{\mathrm{d}}$ due to the volcanic aerosol is detected and attributed. In contrast, no changes in either LWP or cloud fraction could be attributed. The on average almost unchanged LWP is a result of some LWP enhancement for thick, and a decrease for thin clouds.
\end{abstract}

\section{Introduction}

Volcanic eruptions influence the climate by emitting large quantities of solid particles (ash) and gaseous compounds into the atmosphere (Cole-Dai, 2010). Ash particles block sunlight and, therefore, decrease solar radiation reaching the surface. This leads to a cooling, even if the ash settles down due to gravity relatively fast (Robock, 1981).

The gas emissions mainly include water vapor, carbon dioxide, sulfur components (mainly sulfur dioxide $\left(\mathrm{SO}_{2}\right)$ ), and nitrogen (Mather et al., 2004). Chemical processes convert $\mathrm{SO}_{2}$ to sulfuric acid $\left(\mathrm{H}_{2} \mathrm{SO}_{4}\right.$; sulfate aerosol) in the troposphere at relatively short time spans of few days, while in the stratosphere, the conversion can take weeks up to months (Rose et al., 2001).

Sulfate aerosols, injected from a large volcanic eruption, modify the Earth's radiative budget directly by scattering sunlight and indirectly via interaction with clouds (Sahyoun et al., 2019). The latter is the focus of the present manuscript. A large volcanic eruption as a natural laboratory may help to better understand and quantify how cloud properties are modified in response to anthropogenic aerosols emissions (Inguaggiato et al., 2018; Christensen et al., 2021). 
Imposed effective radiative forcing by aerosol-cloud interactions in warm clouds can be separated into the Twomey effect (Twomey, 1974) and cloud adjustments to radiative forcing (Bellouin et al., 2020). An enhancement in cloud condensation nuclei $(\mathrm{CCN})$ concentrations lead to an increase in cloud droplet number concentration $\left(N_{\mathrm{d}}\right)$, resulting in a smaller effective radius $\left(r_{\mathrm{e}}\right)$ if cloud liquid water path (LWP) is constant. Consequently, scattering cross section and the cloud albedo are enhanced, causing clouds to reflect more sunlight back to space, which is known as Twomey effect (Twomey, 1974). Anthropogenic aerosols modify cloud particle size distributions, which reduces the efficiency of collision-coalescence processes, leading to delay in precipitation onset consequently enhancing cloud lifetime (Albrecht, 1989). This infers on average an enhancement in cloud fraction and LWP (Pincus and Baker, 1994; Gryspeerdt et al., 2019). These longer lived clouds reflect more sunlight back to space and cool the atmosphere and surface even more, which is known as lifetime effect (Xue et al., 2008).

Along with the aforementioned effects, there is a large variety of processes that partially offset these effects on clouds, such as a reduced maximum supersaturation if more droplets compete for the available water vapor (Twomey, 1959), a larger evaporation rate of smaller droplets (Small et al., 2009), increased droplet spectrum dispersion (Brenguier et al., 2011; Liu and Daum, 2002), or enhanced evaporation due to cloud-top mixing (Ackerman et al., 2004; Gryspeerdt et al., 2019). Because the different effects oppose each other, the overall changes in the effective radiative forcing cloud be minor on larger scales (Khain et al., 2008; Stevens and Feingold, 2009). In this study, the responses of clouds to aerosols emitted in the Holuhraun volcano eruption were examined. The Holuhraun eruption was the strongest in Europe since the $18^{\text {th }}$ century and emitted substantial amounts of sulfate aerosol (Ilyinskaya et al., 2017). This natural phenomenon has triggered a large effort to investigate the impact of this large aerosol perturbation on cloud properties. (Malavelle et al., 2017).

Malavelle et al. found a significant reduction in $r_{\mathrm{e}}$ in satellite data, but only insignificant alterations of LWP. They further concluded that several general circulation models overemphasize LWP increase in response to the additional aerosol. However, McCoy et al. (2018) did find an increase in LWP when carefully conditioning on moisture convergence. In addition, ambiguous results, with LWP responses of either sign, were obtained by (Toll et al., 2017) when analyzing multiple volcanic eruptions.

Following these previous studies, we chose the Holuhraun eruption to investigate the response of LWP, cloud fraction, and its corresponding radiative effect in response to additional $\mathrm{CCN}$ in the emission plume of the volcano, employing simulations in cloud resolving resolution and comparing them to satellite observations.

\section{Model and data}

The present study focuses on a detection and attribution approach, using cloud resolving simulations (kilometer-scale resolution, Stevens et al., 2020) in combination with the analysis of satellite data. A pair of simulations over the North Atlantic ocean around the Holuhraun volcano on Iceland was employed (Figure 1). The model used is the ICOsahedral Non-hydrostatic model (ICON, Zängl et al., 2015). The ICON model is developed by a collaboration between the German Meteorological Service and the Max Plank Institute for Meteorology (Klocke et al., 2017). It can be used from global simulation in the climate scale (Giorgetta et al., 2018) to high resolution large eddy simulations (Heinze et al., 2017). Here, the physics package of the 


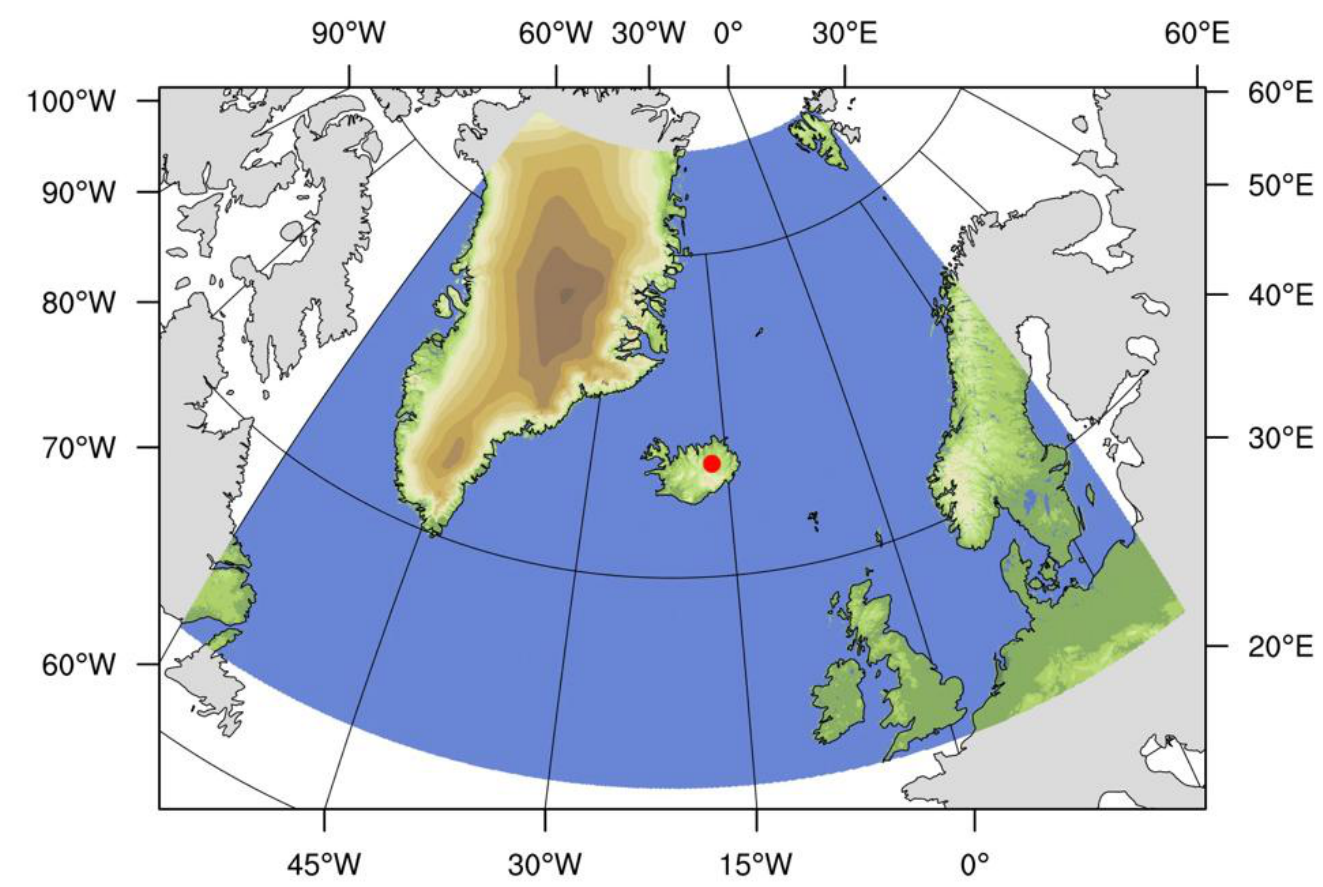

Figure 1. Domain of the ICON-NWP simulations over the North Atlantic ocean $\left(60^{\circ} \mathrm{W}-20^{\circ} \mathrm{E}, 50^{\circ} \mathrm{N}-80^{\circ} \mathrm{N}\right)$ which included the Holuhraun volcano on Iceland that erupted in September 2014. The model resolution is approximately $2.5 \mathrm{~km}$ in the horizontal (R2B10 triangular grid). Red dot indicates location of Holuhraun volcano.

numerical weather prediction (NWP) variant is used (ICON-NWP). The resolution corresponds to approximately $2.5 \mathrm{~km}$ in the horizontal (R2B10 triangular grid). In the vertical, 75 layers with top height at $30 \mathrm{~km}$ were chosen.

The physics package of ICON-NWP includes a comprehensive double moment cloud liquid and ice microphysical scheme (Seifert and Beheng, 2006). Because of using a rather fine resolution, deep convection is considered to be resolved, whereas, for shallow convection, the parameterization scheme by Tiedtke (1989) with modifications by Bechtold et al. (2008) was used. To achieve a more realistic representation of the Twomey effect, we furthermore coupled the hydrometeor number concentrations from the double moment microphysical scheme to the radiation scheme as proposed in Kretzschmar et al. (2020).

Initial and boundary conditions were derived from the European Centre for Medium-Range Weather Forecast (ECMWF) Integrated Forecasting System (IFS) operational analysis. The 2014 Holuhraun eruption was a fissure eruption that started on 20 August 2014 and ended on 25 February 2015. By 7 September 2014, the lava field had extended more than $11 \mathrm{~km}$ to the north (Kolzenburg et al., 2017). We choose the period from 1 to 7 September 2014 for our analysis because the lava field had developed sufficiently in this period and substantial amounts of $\mathrm{SO}_{2}$ had been emitted into the atmosphere, while, at the same time, a well-defined plume is observable. An additional feature in simulations that must be mentioned, is the implementation of a satellite simulator into the model. Satellites are essential tools to assess the character of clouds due to their global coverage and availability (Lai et al., 2019). Differences between model simulations and satellite retrievals stem in 
part from a different definition of the respective quantities that are compared. Therefore, one approach to reduce inconstancy between model simulations and satellite retrievals is to use satellite simulators in models to mimic the observational processes (Roh et al., 2020). The COSP satellite simulator (Bodas-Salcedo et al., 2011) is an open source work package developed by CFMIP (Cloud Feedback Model Intercomparison Project) to replicate active and passive satellite data using variables from the model as an input (Webb et al., 2017). In this study, just satellite simulator for MODIS (Moderate Resolution Imaging Spectroradiometer) observations (Pincus et al., 2012) was used. The COSP simulator uses several model variables as input such as temperature, pressure, cloud fraction and cloud water content (Kretzschmar et al., 2019) to generate what the MODIS retrievals would capture given the simulated clouds fields (Saponaro et al., 2020).

In the cloud-resolving simulation (each grid box is either fully cloudy or clear), the use of sub-grid variability, one of the features of COSP for application in general circulation models, was not necessary. In order to evaluate COSP related variables in our simulations, the collection 6.1 Level-2 MODIS-Aqua optical and physical cloud data product was used (Platnick et al., 2017); therefore, swaths with $1 \mathrm{~km}$ spatial resolution for $r_{\mathrm{e}}$, cloud optical thickness $\left(\tau_{\mathrm{c}}\right)$ and LWP were used and remapped to the model resolution to have an accurate comparison. Furthermore, the planetary albedo at the top of the atmosphere is analyzed as retrieved by the Clouds and the Earth's Radiant Energy System (CERES) instrument onboard the Aqua satellite (Su et al., 2015; Loeb et al., 2016).

\subsection{CCN activation}

The ICON-NWP version applied in this study does not contain an interactive aerosol model; therefore, in this section, we discuss how CCN are activated into clouds droplets in the default model setup and afterward we introduce a new method for CCN activation in microphysical scheme, which had specifically been developed for this study. In the default setup of ICON, CCN activation uses a parameterization that employs a functional dependency of grid scale vertical velocity and pressure to derive the number of newly activated CCN (Hande et al., 2016). Hande et al. (2016) performed model simulations that considered a multi-modal interactive aerosol scheme to provide information on the formation and transport of aerosols in Europe and, by using the parameterization of Abdul-Razzak and Ghan (2000, ARG), derived CCN number concentrations for different vertical velocities for a selected date (30 April 2013). This parameterization thus assumes a temporally and spatially constant profile of $\mathrm{CCN}$ which is representative for $\mathrm{CCN}$ background over Europe. For that reason, this parameterization alone can not provide information about $\mathrm{CCN}$ concentration within a plume of volcanic aerosol.

In order to more accurately represent the aerosol plume, we use look-up tables that contain the number of activated $\mathrm{CCN}$ as a function of pressure $p$ and vertical velocity $w$ as an input for the ICON simulation. The number of activated CCN is interpolated from these look-up tables considering the values of $p$ and $w$ in each grid-box within the cloud microphysical scheme. This method had been developed for the ICON model in its large-eddy setup (Costa-Surós et al., 2020) and has been implemented into ICON-NWP for our study. While dedicated interactive-aerosol simulations were performed to create the look-up tables in Costa-Surós et al. (2020), we use the Copernicus Atmospheric Monitoring Service (CAMS) reanalysis (Inness et al., 2019) to obtain the information about the spatial-temporal distribution of the aerosol mass mixing ratio by aerosol species. The CAMS reanalysis provides aerosol mass mixing ratios at 60 hybrid sigma/ pressure levels up to $0.1 \mathrm{hPa}$, and covers the 2003 to 
2020 period. Using the aerosol mass mixing ratio from the CAMS reanalysis, along with using the ARG parametrization, that calculates the number of activated aerosols employing the Köhler theory (Köhler, 1936), we created look-up tables of activated $\mathrm{CCN}$ for our simulation.

In our study, the ARG-parameterization is employed offline, by running a box model setup and using aerosol mass mixing ratio from the CAMS reanalyses as an input for various vertical velocities. The ARG-parameterization has been used in microphysical schemes in a wide range of resolutions before, ranging from global climate models to cloud resolving models (Ghan et al., 2011; West et al., 2014; Luo et al., 2008). The ARG parameterization is based on the competition between aerosol particles for available water vapor which depends on aerosol particle composition, size distribution and most importantly the supersaturation forcing rate obtained by the updraft. We evaluate supersaturation $S_{0, i}$ at ten specific values of vertical velocity used in the look-up tables (see Costa-Surós et al., 2020). After calculating $S_{\max }$, the critical radius of activation for each aerosol mode is obtained in the box model. When the supersaturation for each aerosol mode is smaller than maximum supersaturation $S_{\max } \geq S_{0, i}$, the environment has gained the needed supersaturation to activate the particles. Using this approach, an observations-tied spatially-temporally varying input number concentration of activated $\mathrm{CCN}$ for ten prescribed vertical velocity classes was produced. In the CAMS reanalyses data, the aerosols emitted from the Holuhraun volcano are not represented: it is firstly not constrained by the data assimilation. CAMS assimilates MODIS aerosol optical depth (AOD) retrievals (Levy et al., 2013), but due to the presence of extensive clouds in the region of interest, MODIS was not able to capture sufficient information about AOD. Secondly, it is also not included in the model simulation, because in the emission source model of CAMS, no volcanic emissions are considered. Therefore, the CAMS data was used to obtain background spatial and temporal aerosols concentration and in order to implement aerosol concentrations inside the plume, the sulfate aerosol concentration in CAMS was scaled based on the $\mathrm{SO}_{2}$ emission monitored by Ozone Mapping and Profile Suite (OMPS) satellite retrievals which will be explained in more detail in the next session (Yang, 2017).

\subsection{The volcanic-aerosol plume in the model simulations}

Lava flows and emitted gases from volcanic eruptions are the most common features that remotely can be monitored globally and at different time scales. $\mathrm{SO}_{2}$ is one of the most common gases emitted from volcanic eruptions and can be retrieved by spaced-based sensors (Fioletov et al., 2020). In this study, the OMPS data product (Level2) for $\mathrm{SO}_{2}$ was used. This data set provides information about vertically integrated $\mathrm{SO}_{2}$ (in Dobson units, DU). The $\mathrm{SO}_{2}$ retrievals for 1 to $7 \mathrm{September} 2014$ for the lower troposphere are shown in Figure 2.

The $\mathrm{SO}_{2}$ plume was detected on 1 September shortly after the beginning of the eruption and evolved over time mostly eastwards, towards Scandinavia. Former studies compared OMPS satellite retrievals with surface observations for the Holuhraun eruption and showed that satellite retrievals are able to detect spatial and temporal evolution of the volcanic plume (Ialongo et al., 2015). In this study, we performed two simulations over the domain shown in Figure 1, one with background aerosol concentrations only, which is referred to as the no-volcano simulation, and one with scaling the sulfate concentrations in the CAMS reanalysis data within the plume as defined by the OMPS satellite retrievals, referred to as the volcano simulation in this article. As shown in Figure 2, grid-points with $\mathrm{SO}_{2}$ concentrations in the lower troposphere exceeding $1 \mathrm{DU}$ are considered 


\section{Sep}
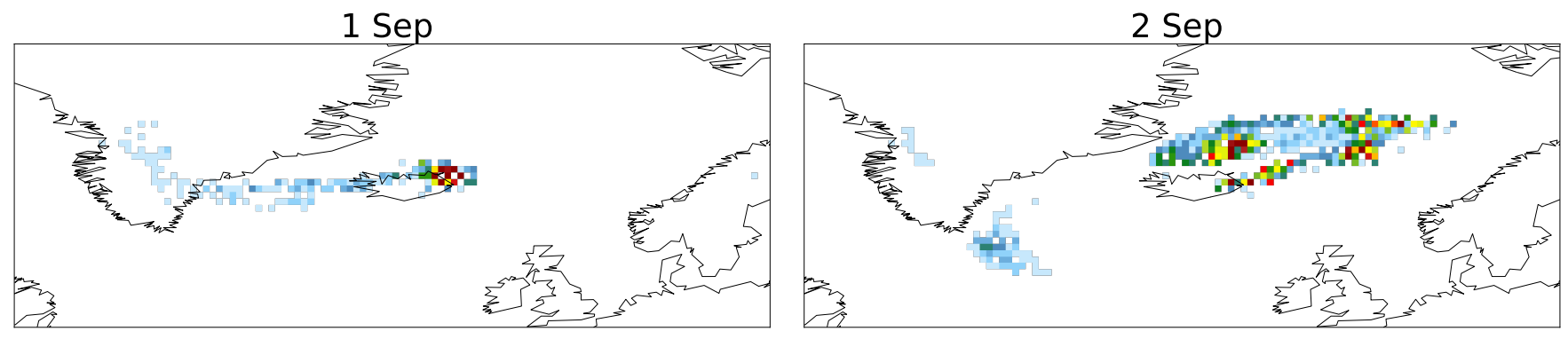

\section{Sep}
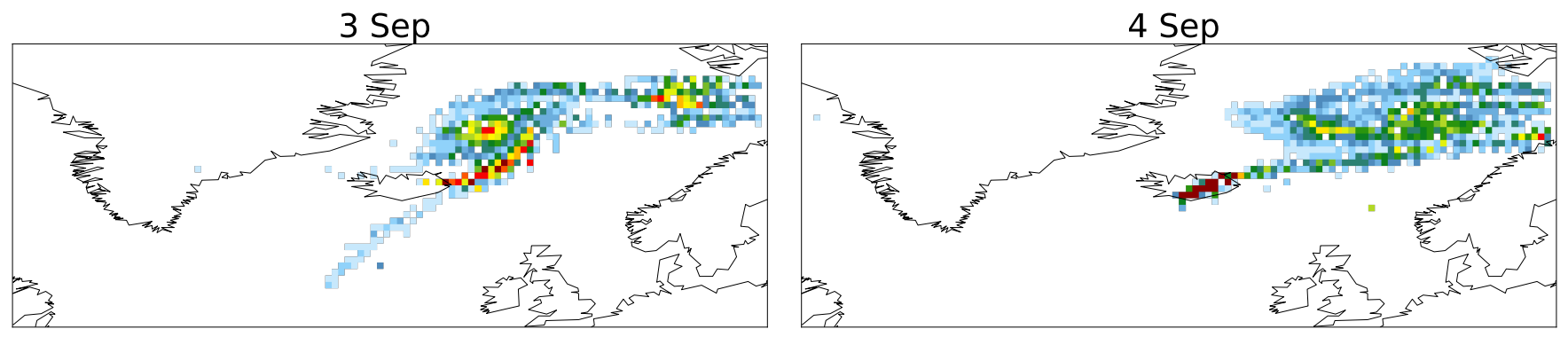

\section{Sep}
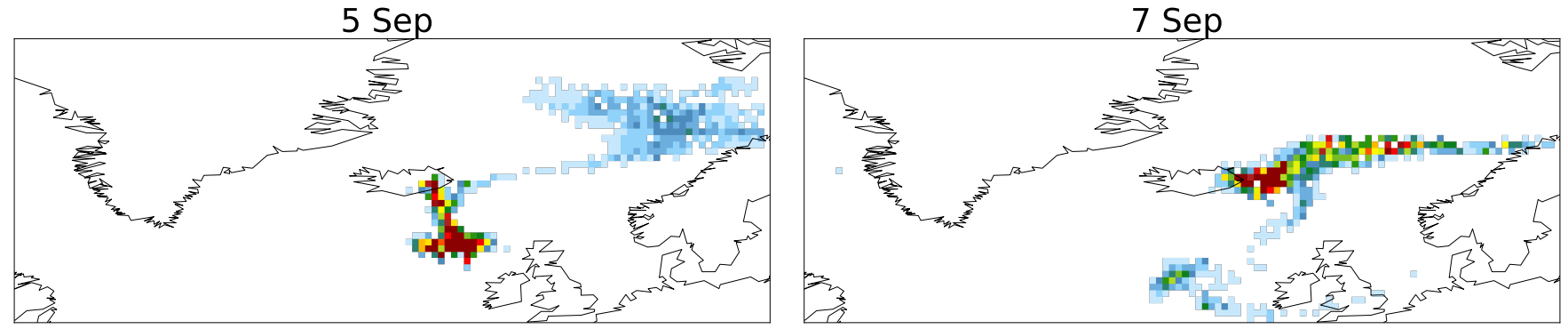

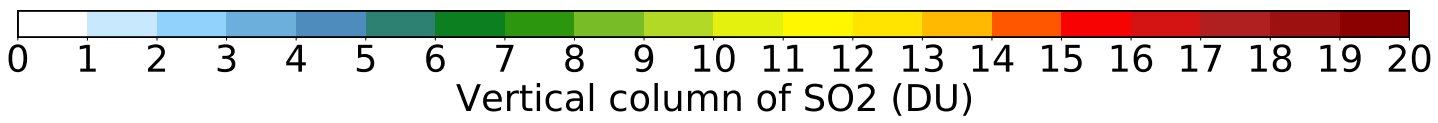

Figure 2. Total vertical column amount of $\mathrm{SO}_{2}$ associated with the ground pixel retrieved using a prescribed $\mathrm{SO}_{2}$ profile centered at $3 \mathrm{~km}$ (in Dobson units) from 1 to 7 September 2014 obtained from OMPS (Yang, 2017) satellite retrievals. No data are available for 6 September 2014.

to constitute the plume. For these grid-points, a scale factor field was computed by dividing the $\mathrm{SO}_{2}$ concentrations retrieved within the plume by the mean $\mathrm{SO}_{2}$ concentration for the entire domain outside the plume region. In the next step, the sulfate aerosol mass mixing ratio from the CAMS reanalyses was scaled inside of plume by these scaling factors before deriving a new CCN distribution that now considers the volcanic plume with the enhancement consistent with the OMPS satellite retrievals.

Figure 3 shows the geographical distribution of vertical-mean number of activated CCN for 2 September 2014 with a background sulfate aerosol concentration (a and c) and scaled sulfate concentration ( $b$ and d) for two different prescribed vertical velocities $\left(0.599 \mathrm{~m} \mathrm{~s}^{-1}\right.$ and $\left.4.64 \mathrm{~m} \mathrm{~s}^{-1}\right)$. As is mentioned in section 2.1, the strength of the updraft corresponds to maximum supersaturation in the ARG-parameterization. Therefore, more CCN gets activated at higher vertical velocity. In Figure 3, the 

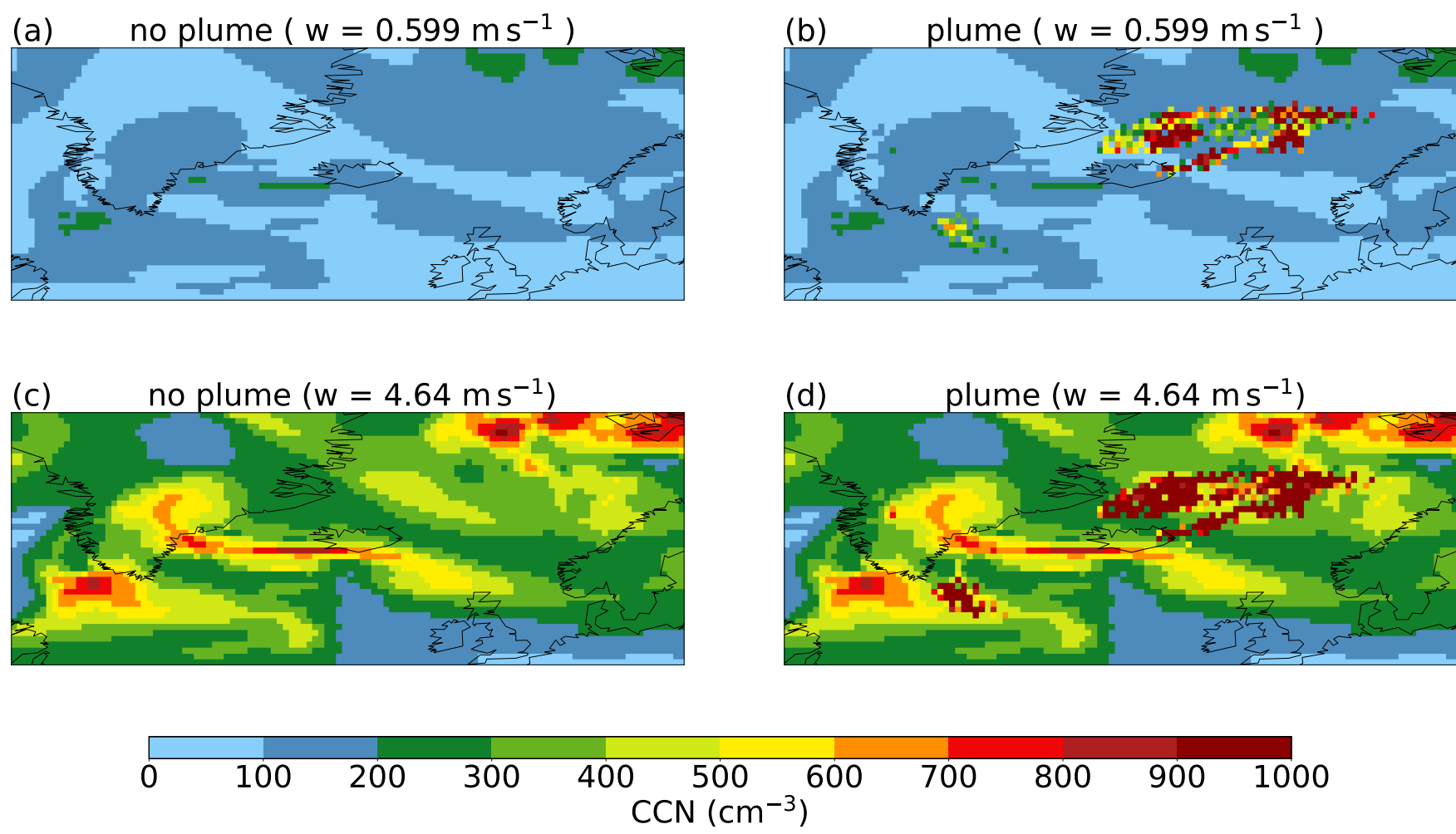

Figure 3. Number of column-mean activated CCN $\left(\mathrm{cm}^{-3}\right)$ for 2 September 2014 for two different vertical velocities $\left(\mathrm{w}=0.55 \mathrm{~m} \mathrm{~s}{ }^{-1}\right.$, upper panels, and $\mathrm{w}=4.6 \mathrm{~m} \mathrm{~s}^{-1}$, lower panels). Left panels (no-plume) correspond to background concentrations of aerosols and right panels (plume) correspond to scaled aerosol concentrations.

location of the plume can smoothly be identified. This information lead us to perform two simulations one with a background activated CCN concentration (left panels) referred as no-volcano simulation, and one with scaled activated CCN concentration (right panels) referred to as volcano simulation.

\section{Results}

The present study aims at a detection and attribution approach, assessing the differences in cloud properties within and outside the volcanic plume by comparing a factual and a counterfactual simulation with satellite observations. This aims to evaluate how cloud microphysical properties ( $N_{\mathrm{d}}$ and LWP) behave differently in and outside the volcano plume.

To address this scientific question, grid cells that are located inside and outside of volcano plume are analyzed and compared to each other in volcano and no-volcano (factual and counterfactual) simulations along with MODIS satellite retrievals for the 7 days starting on 1 September 2014. In the no-volcano simulation, there is no CCN enhancement due to the volcanic emissions 

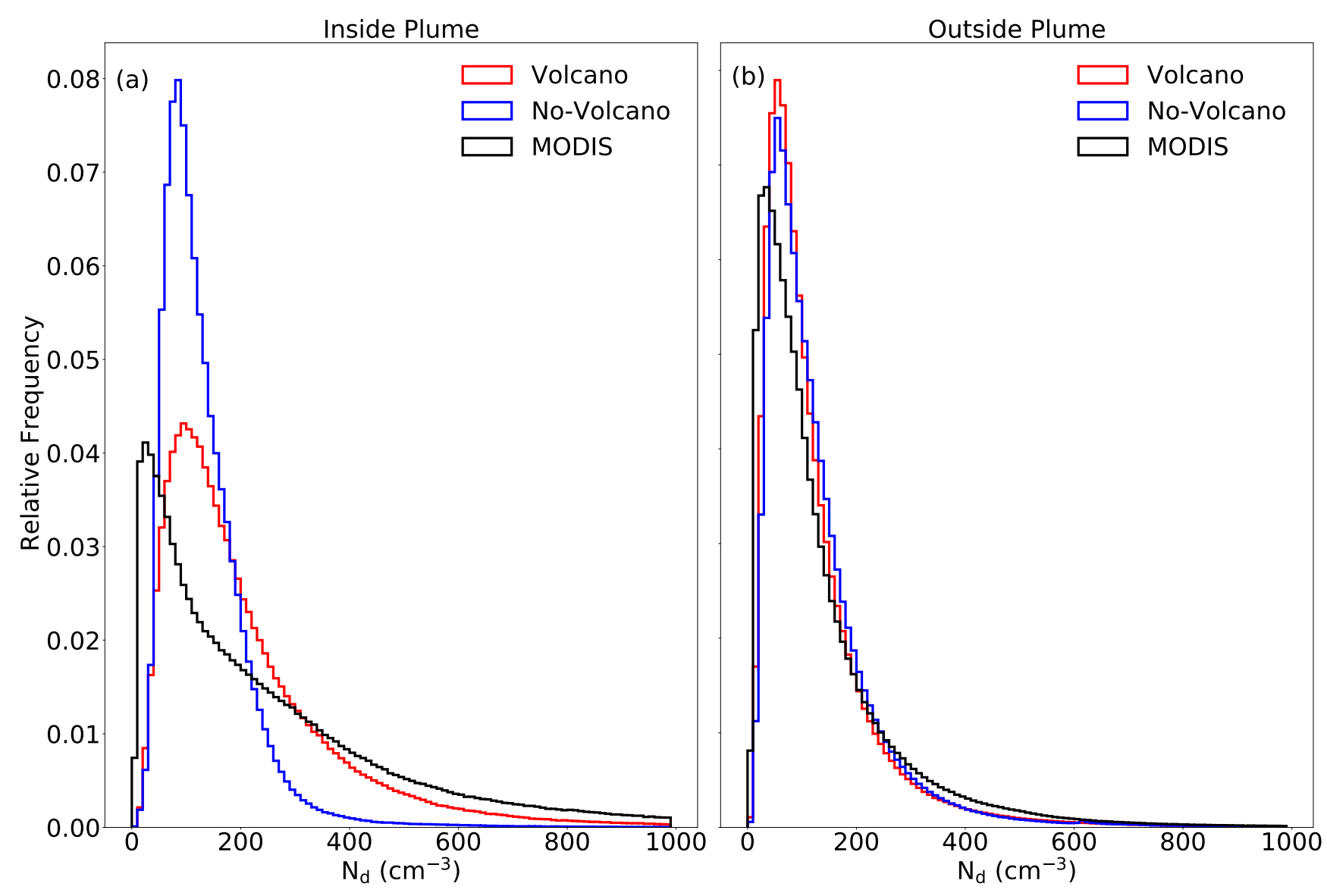

Figure 4. Relative frequency distribution of $N_{\mathrm{d}}\left(\mathrm{cm}^{-3}\right)$ for liquid clouds, inside of the plume (a) and outside the volcano plume (b) in the volcano simulation (red), the no-volcano simulation (blue) and MODIS Aqua level-2 data (black). The PDF shows the spatio-temporal variability for the MODIS overpass time for the seven days.

(left column in Figure 3). Nevertheless, the grid points that are located inside of the volcano plume are compared to the ones outside the plume to assess differences due to different meteorological conditions.

$N_{\mathrm{d}}$ is the first microphysical variable we assess. $N_{\mathrm{d}}$ is not directly retrieved by the operational MODIS satellite retrievals. Instead, $r_{\mathrm{e}}$ and $\tau_{\mathrm{c}}$ are retrieved using the method described by Nakajima and King (1990). On the basis of such retrievals, assuming clouds that behave like adiabatic ones, $N_{\mathrm{d}}$ can be computed as follows (Grosvenor et al., 2018):

$N_{\mathrm{d}}=\gamma \tau_{\mathrm{c}}^{\frac{1}{2}} r_{\mathrm{e}}^{-\frac{5}{2}}$

165 In this relation, $\gamma$ depends mainly on the adiabatic condensation rate and can be approximated as $1.37 \cdot 10^{-5} \mathrm{~m}^{-\frac{1}{2}}$ (Quaas et al., 2006). In order to obtain $N_{\mathrm{d}}$ by Equation 1 in our analyses both in simulations and MODIS, $r_{\mathrm{e}}$ less than $4 \mu \mathrm{m}$ and $\tau_{\mathrm{c}}$ less than 4 were excluded from data set because they are less reliable (Nakajima and King, 1990). For consistency, $N_{\mathrm{d}}$ is derived from the 
COSP diagnostics of $\tau_{\mathrm{c}}$ and $r_{\mathrm{e}}$ (see section 2) in the same way as done in the MODIS retrievals. The model output is sampled at the time of the MODIS Aqua overpass of approximately 13.30 LST (Local Sidereal Time).

In the subsequent figures, in each panel the blue line is for the no-volcano run, the red line is for the volcano run and the black line is for the MODIS observations. Figure 4 shows the relative frequency distribution of $N_{\mathrm{d}}$. The right panel (outside of plume) indicates that the $N_{\mathrm{d}}$ distribution outside of the volcano plume for both simulations are, as expected, very similar because the meteorology is the same and there is no additional aerosol. Comparing both simulations to MODIS retrievals demonstrates that the simulated $N_{\mathrm{d}}$ distribution is close to what is obtained from the satellite retrievals. In contrast, for the grid points inside the plume, it can be seen that $N_{\mathrm{d}}$ is substantially enhanced in the volcano run compared to the no-volcano run as was expected due to the larger concentration of activated CCN inside the volcano plume. The $N_{\mathrm{d}}$ distribution for MODIS shows that these observations are considerably closer to the volcano run with respect to the higher probability of large $N_{\mathrm{d}}$ even if at lower concentrations there is a systematic discrepancy between MODIS data and both simulations. For such low concentrations, there is the possibility that the satellite data are biased (Grosvenor et al., 2018). For broken clouds, MODIS shows overly large $r_{\mathrm{e}}$, which implies overly low $N_{\mathrm{d}}$ (Eq. 1). Nevertheless, the results for the large $N_{\mathrm{d}}$ concentrations, and the overall good agreement between the simulations and satellite retrievals (also outside the plume) allow for clear detection of the enhancement of $N_{\mathrm{d}}$ inside the volcanic plume and its attribution to the volcanic aerosol.

The mean values for $N_{\mathrm{d}}$ are listed in Table 1. The mean $N_{\mathrm{d}}$ in the plume, compared to the mean of the distribution outside the plume, is enhanced by $77 \%$ in volcano run compared to no $(0 \%)$ change in the no-volcano run. The enhancement value in MODIS is $78 \%$ which almost exactly is the same as in the volcano run. The mean $N_{\mathrm{d}}$ outside the plume is $134 \mathrm{~cm}^{-3}, 128 \mathrm{~cm}^{-3}$ and $135 \mathrm{~cm}^{-3}$ for no-volcano, volcano simulations and MODIS respectively, showing that outside of plume $N_{\mathrm{d}}$ didn't change considerably between simulations because the meteorology is same and there is no additional activated CCN, and showing good consistency between both model runs and the satellite retrievals.

Figure 5 shows the same analyses as Figure 4 but for LWP. The distribution of LWP for the region outside the volcano plume is not significantly different between the two simulations, as expected. The mean values for LWP (Table 1) in both simulations is the same at $151 \mathrm{~g} \mathrm{~m}^{-2}$; furthermore, the MODIS mean value of $149 \mathrm{~g} \mathrm{~m}^{-2}$ is close to the simulations which demonstrate the accuracy of clouds simulations. This is also true for the entire distribution (Figure 5). Considering the simulated profiles, in the simulation with volcano emissions included, there is a decrease in the probability of shallower clouds (with lower LWP) and an increase in the probability of thicker clouds (with higher LWP) compared to the no-volcano simulation. The MODIS distribution for LWP inside the plume indicates that the probability for shallower clouds is less than what the simulations show, but the probability for thicker clouds is higher than in the no-volcano run, albeit also less than in the volcano run. In terms of the mean values for LWP (Table 1) for inside of plume, the simulations indicate a slight enhancement (+6\%) attributable to the different weather conditions (plume enhancement in the no-volcano run), and a strong enhancement ( $+30 \%)$ in the volcano run. The difference suggests that the model shows an LWP enhanced by $24 \%$ due to additional CCN inside of volcano plume. MODIS, however, is very close to the result of the no-volcano run for the average values. This almost zero enhancement on 


\begin{tabular}{|l|c|c|c|c|c|c|}
\hline Variables & $\begin{array}{c}\text { MODIS } \\
\text { outside } \\
\text { plume }\end{array}$ & $\begin{array}{c}\text { MODIS } \\
\text { plume en- } \\
\text { hancement }\end{array}$ & $\begin{array}{c}\text { no-vol } \\
\text { outside } \\
\text { plume }\end{array}$ & $\begin{array}{c}\text { no-vol } \\
\text { plume en- } \\
\text { hancement }\end{array}$ & $\begin{array}{c}\text { vol outside } \\
\text { plume }\end{array}$ & $\begin{array}{c}\text { vol plume } \\
\text { enhance- } \\
\text { ment }\end{array}$ \\
\hline$N_{\mathrm{d}\left(\mathrm{cm}^{-3}\right)}$ & 135 & $78 \%$ & 134 & $0 \%$ & 128 & $77 \%$ \\
\hline LWP $\left(\mathrm{g} \mathrm{m}^{2}\right)$ & 149 & $7 \%$ & 151 & $6 \%$ & 151 & $30 \%$ \\
\hline RWP $\left(\mathrm{g} \mathrm{m}^{2}\right)$ & - & - & 13 & $53 \%$ & 13 & $38 \%$ \\
\hline $\begin{array}{l}\text { Cloud } \\
\text { fraction }(\%)\end{array}$ & 52 & $29 \%$ & 58 & $32 \%$ & 58 & $40 \%$ \\
\hline $\begin{array}{l}\text { All-sky } \\
\text { Albedo }\end{array}$ & 0.39 & $18 \%$ & 0.33 & $27 \%$ & 0.35 & $42 \%$ \\
\hline $\begin{array}{l}\text { Cloudy-sky } \\
\text { Albedo }\end{array}$ & 0.44 & $9 \%$ & 0.46 & $0 \%$ & 0.45 & $7 \%$ \\
\hline
\end{tabular}

Table 1. Mean values for $N_{\mathrm{d}}$, LWP, RWP, total cloud fraction and albedo at top of atmosphere for MODIS (CERES for the albedo), the novolcano simulation and volcano simulation. The values are computed for outside of plume and enhancement inside of plume which computed as ( $\left.\frac{\text { mean for inside of plume }- \text { mean for outside of plume }}{\text { mean for outside of plume }}\right)$.

average, however, seems to come about by a decrease in LWP for the clouds with low LWP, and an enhancement of LWP for large LWP values (Figure 5. This is qualitatively consistent with the results of the ICON-NWP model. The model, however, exaggerates the increase in large LWP values, leading to the exaggerated mean increase.

The question is now what is the underlying process leading to an increase in LWP in the volcano simulation? One reason is the suppression of precipitation (e.g., Seifert et al., 2012). Therefore, the distribution of rain water path (RWP) was analyzed to investigate the alteration of precipitation inside and outside the volcano plume in both, the volcano and no-volcano simulations. The comparison is shown in Figure 6. Since the precipitation information is not available from MODIS or other satellite retrievals, RWP is only depicted for the simulations. Inside the volcano plume, there is a decrease in light rain and an increase in heavy rain for the volcano simulation, compared to the no-volcano simulation. In terms of mean values for RWP (Table 1), there is a decrease in the volcano run by $15 \%$ on average, while the precipitation profile for outside of plume is quite similar which is in the agreement of the fact that LWP for outside of plume didn't alter significantly. Moreover, suppression in precipitation can also lead to enhancement in cloud horizontal extent (cloud fraction). Therefore, the modification in cloud fraction was examined in simulations and MODIS. The analyses for mean values of total cloud fraction in Table 1 demonstrates that, in the volcano simulation, cloud fraction is enhanced in the plume compared to outside the plume by $40 \%$, while the enhancement is only $32 \%$ in the no-volcano simulation. However, even in the no-volcano simulation, cloud fraction inside of plume is higher than outside of plume by $32 \%$ due to the different weather conditions, and this is consistent with what MODIS shows (29\%).

Finally, the effect on radiation (indicative of the effective radiative forcing due to the modification of cloud properties by the volcanic aerosol) is examined. Therefore the TOA albedo was analyzed inside and outside of plume in simulations and CERES level-2 footprint data (Su et al., 2015). For the comparison, the simulation output was remapped to $20 \mathrm{~km}$ horizontal 


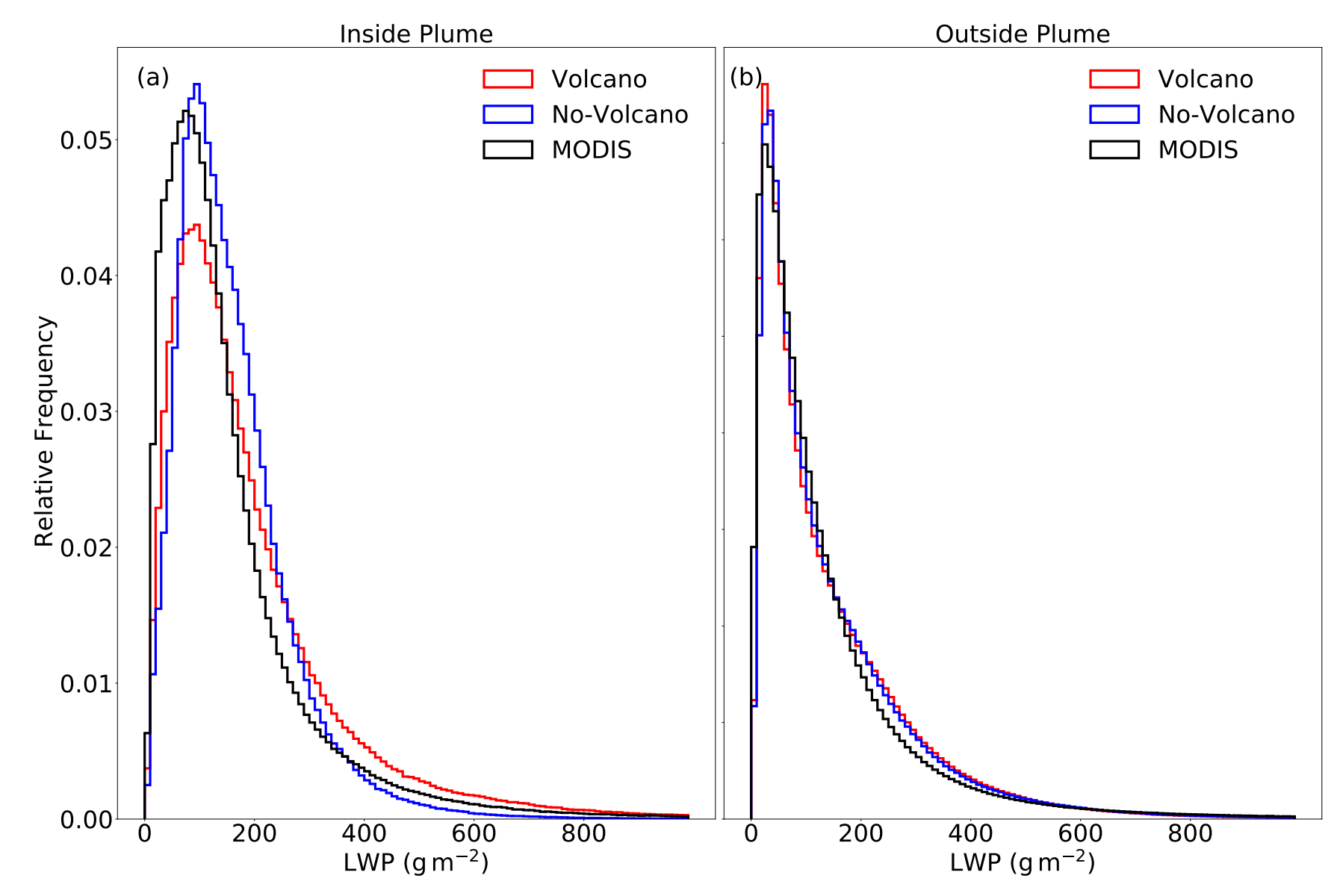

Outside Plume

Figure 5. As Figure 4, but for $\operatorname{LWP}\left(\mathrm{g} \mathrm{m}^{-2}\right)$.

resolution to be consistent with the resolution of the CERES footprint. In Figure 7 TOA albedo for the cloudy sky is depicted for inside and outside the volcano plume for both simulations and CERES data. Clear sky was excluded because, in the model, no aerosol-radiation interactions are considered, but in the CERES this effect is in the data and would bias the analysis for clear sky. An additional important aspect that should be considered, is that the TOA albedo distribution is considered here for liquid clouds with $\tau_{\mathrm{c}}$ more than 4 because in obtaining $N_{\mathrm{d}}$ the data with $\tau_{\mathrm{c}}$ less than 4 were excluded as well. Considering the TOA albedo distribution inside the plume, it is seen that in the volcano simulation, there is a higher probability for TOA albedo larger than 0.6 compared to the no-volcano simulation. In the CERES data, there is a peak at TOA albedo between 0.4 and 0.6 that is not as pronounced in either simulation. In turn, the probability for TOA albedo larger than 0.7 is smaller in the data than in both simulations. This bias, however, is clear outside the plume but much less so inside the plume - possibly indicative of the albedo enhancement due to the volcanic aerosol.

For the mean values (Table 1), in turn, clear sky data were taken into account to be able to see the influence of cloud fraction changes on modifying TOA albedo. The difference in mean values between inside and outside the plume in the 

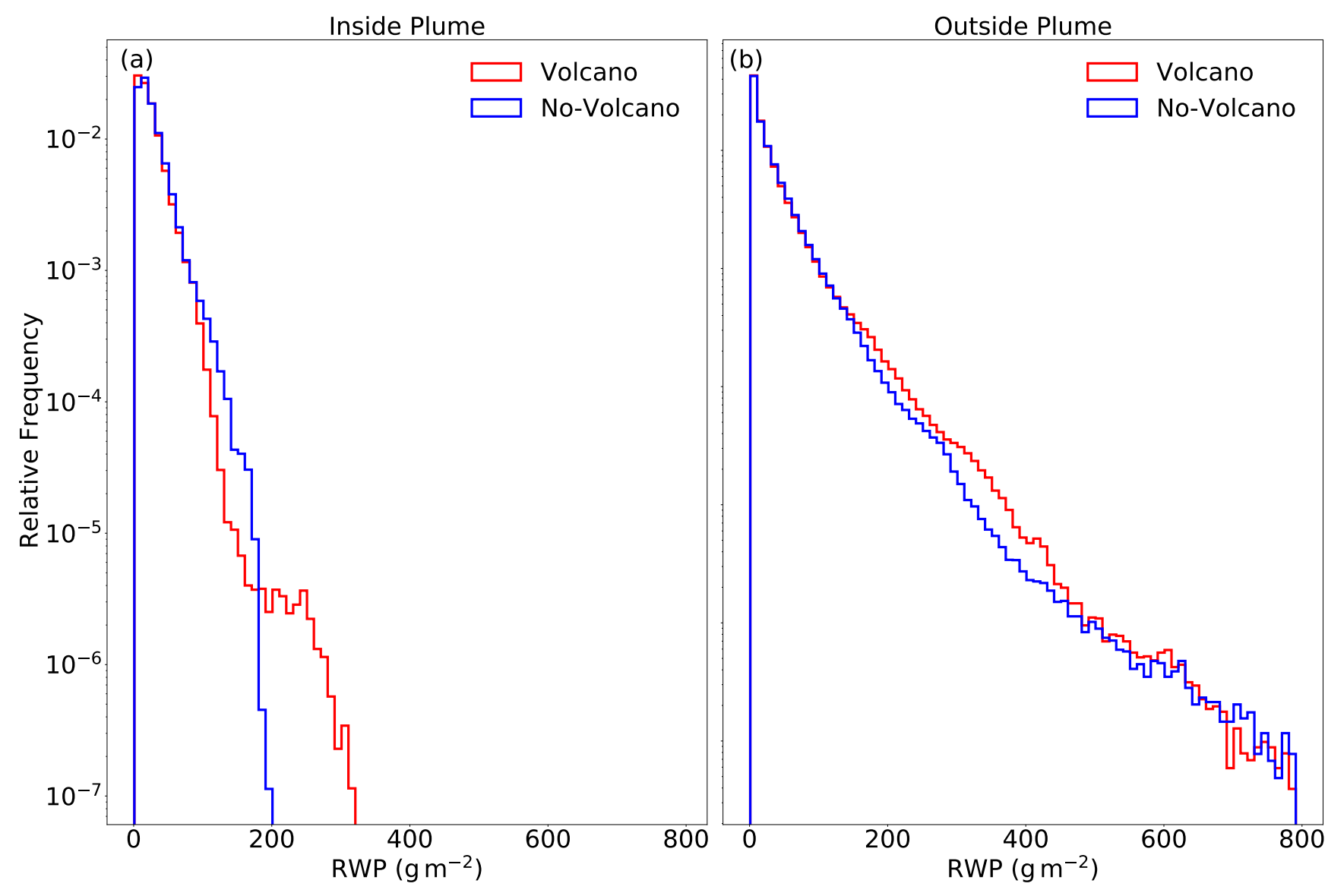

Figure 6. Relative frequency distribution of RWP profile in logarithmic scale for inside of plume (a) and outside of volcano plume (b) in volcano simulation (red) and no-volcano simulation (blue).

volcano simulation is $15 \%$ larger compared to no-volcano simulation. In CERES data there is an $18 \%$ enhancement inside the volcano plume compared to outside the plume. When compared to the difference between inside and outside the plume in the no-volcano simulation (27\%), it is difficult to conclude that there is a signal of alteration in TOA albedo in CERES data. We also analyzed cloudy sky TOA albedo mean values in simulations and CERES. The values in Table 1 demonstrate an enhancement of $9 \%$ in CERES and $7 \%$ in volcano simulation while no changes were obtained in no-volcano simulation. The daily mean incoming solar radiation was obtained $260 \mathrm{~W} \mathrm{~m}^{-2}$; therefore, effective radiative forcing except cloud cover effect can be estimated as $10 \mathrm{~W} \mathrm{~m}^{-2}$ in CERES and $8 \mathrm{~W} \mathrm{~m}^{-2}$ in volcano simulation. 

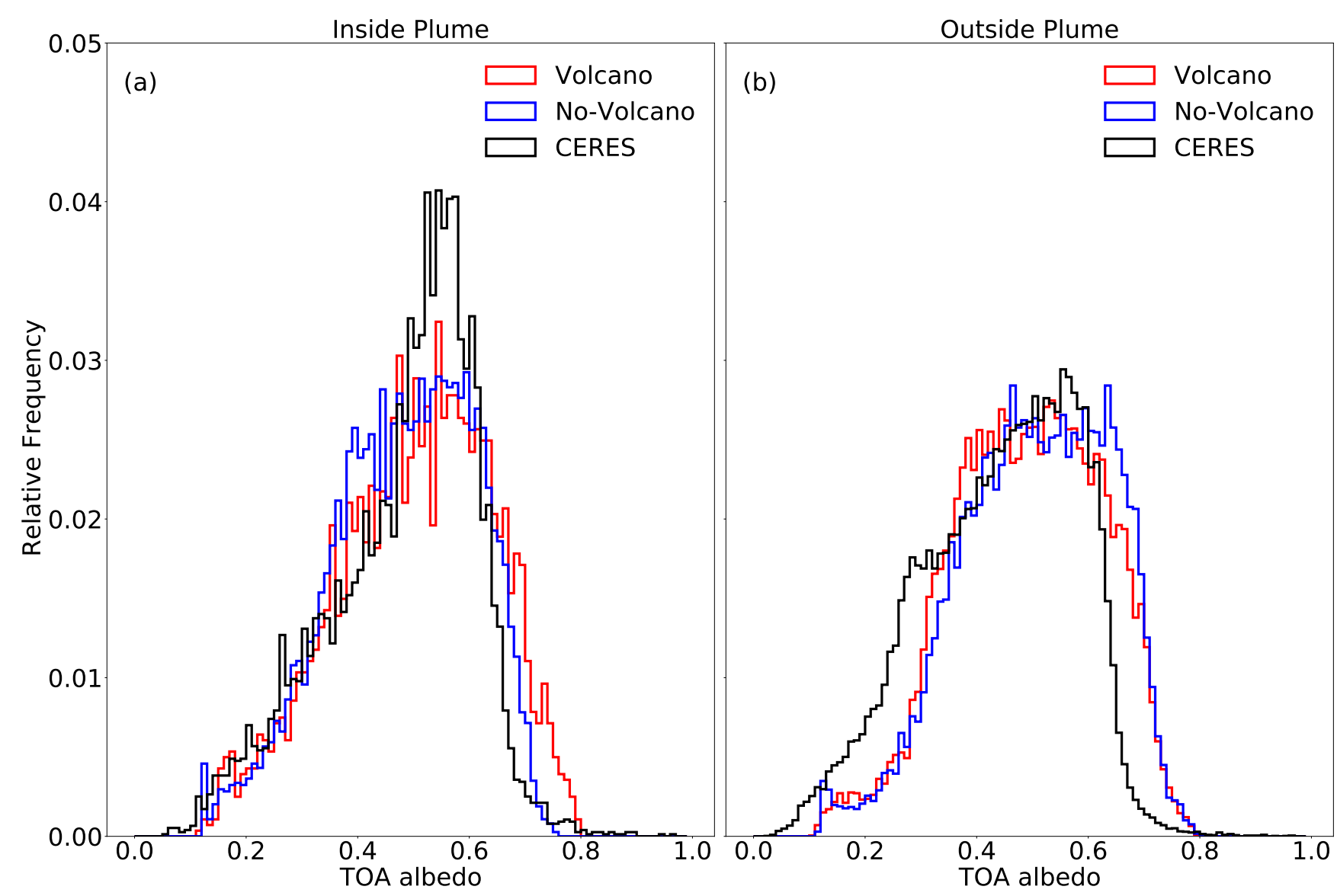

Figure 7. Relative frequency distribution of TOA albedo profile for inside of plume (a) and outside of volcano plume (b), in volcano simulation (red), no-volcano simulation (blue), and CERES level-2 footprint data (black).

\section{Conclusions}

In this study, the impact of aerosols emitted by the Holuhraun volcanic eruption on liquid clouds was assessed from a pair of cloud-system resolving simulations with and without the enhancement in CCN due to the volcanic emission, and from MODIS and CERES satellite retrievals. The COSP simulator was implemented in the model to allow for an apples-to-apples comparison between the simulations and satellite data. To identify the impact of the additional aerosol on cloud microphysical properties, areas located inside and outside the volcano plume were compared in terms of their statistical distributions. In the no-volcano (counterfactual) simulation, only the differences in weather conditions are sampled. In the in volcano (factual) simulation, in addition, there is the effect of then CCN enhancement on the clouds. To the extent the inside vs. outside-plume difference is consistent between the satellite retrievals and the volcano simulation, but not between the satellite retrievals and the no-volcano simulation detection and attribution of the effect of the aerosol on the clouds is achieved. Our analyses 
indicated that $N_{\mathrm{d}}$ concentration is clearly enhanced inside the volcano plume. This enhancement by almost $80 \%$ is attributable to the additional CCN inside the volcano plume. Our scientific goal in this study was to examine how LWP and cloud fraction respond to the enhancement of the $N_{\mathrm{d}}$ in the volcanic plume. The analysis reveals that in the simulations and MODIS, the LWP is increased inside the plume compared to outside the plume. However, for the mean increase, no attribution to the additional CCN is possible. In turn, there is an indication that at low LWP, there is a decrease in LWP while at large LWP, there is an enhancement. This latter enhancement, however, is exaggerated in the ICON-NWP model simulation. In the model, the reason for the enhancement of LWP in the volcano simulation was the decrease in precipitation compared to no-volcano simulation by $15 \%$ on average, due to a shift from lighter to more heavy rain. Examining cloud fraction - only possible for the mean value - demonstrates that the cloud fraction also increased inside the plume in the volcano simulation compared to the novolcano simulation. Similar to the result for LWP, this mean increase cannot be attributed to the volcanic aerosol. It is unclear for the MODIS data, how much change in cloud fraction between inside and outside the plume is due to the enhancement of cloud lifetime due to the additional CCN and how much simply is because of different weather. To learn about the climate implications, it is essential to identify how the planetary albedo differs inside and outside the volcano plume. In this study, the difference in increase of TOA albedo between inside and outside the volcano plume in the volcano and no-volcano simulations was quantified by at $42 \%$ when considering the volcanic aerosol vs. only $27 \%$ without it, but it is, again, not possible to attribute the enhancement in TOA albedo in the CERES observations.

Overall, the results from this detailed analysis using level-2 satellite observations and cloud-system resolving simulations confirm the key result of Malavelle et al. (2017) that there is a clear, detectable and attributable impact of the volcanic aerosol on the $N_{\mathrm{d}}$, but there is on average only a very small, not attributable, effect on both LWP and cloud fraction. This net result for the case of the Holuhraun volcano for LWP comes about by a slight enhancement of LWP for thick (large-LWP) clouds compensated for by a decrease in LWP in thin (low-LWP) clouds.

Data availability. The ICON model outputs are stored at the German climate computing center (DKRZ) and are available upon request to the corresponding author. The MODIS data were downloaded from the Atmosphere Archive Distribution System (LAADS) Distributed Active Archive Center (DAAC), located in the Goddard Space Flight Center in Greenbelt, Maryland (https://ladsweb.nascom.nasa.gov/). CAMS reanalyses are available from the Atmosphere Data Store (ADS), either interactively through its download web form or by using the CDS API service (https://confluence.ecmwf.int/display/CKB/CAMS). OMPS data was downloaded via https://search.earthdata.nasa.gov/.

Author contributions. MH and JQ conducted this study. JK helped with setting up and running ICON-NWP. KB contributed to producing data for the study. MH prepared the model and observational data. All authors contributed to the interpretation of the results. MH produced the manuscript with the aid of all co-authors.

Competing interests. The authors declare that they have no conflict of interest. 
https://doi.org/10.5194/acp-2022-38

Preprint. Discussion started: 24 January 2022

(C) Author(s) 2022. CC BY 4.0 License.

(c) (1)

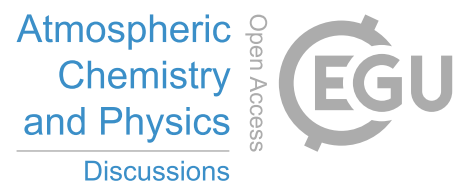

280 Acknowledgements. We appreciatively acknowledge funding by the German Research Foundation (Deutsche Forschungsgemeinschaft, DFG) for funding via the VolCloud project (GZQU 31123-1) as part of the VolImpact research unit. JQ further acknowledges funding by the European Union via its Horizon 2020 project CONSTRAIN (GA 820829). We are thankful for the valuable collaboration with colleagues in the research unit VolImact, especially within VolCloud with the Karlsruhe Institute of Technology, Corinna Hoose and Fatemeh Zarei. We are thankful to the German Meteorological Service (DWD) and the Max Planck Institute for Meteorology to provide the ICON model to the research community, and German Climate Computing Center (Deutsches Klimarechenzentru, DKRZ) to provide the resources to conduct the simulations. We also thank NASA for providing the satellite retrievals employed in this study. 


\section{References}

Abdul-Razzak, H. and Ghan, J.: Dri Dw, Journal of geophysical research, 105, 6837-6844, https://doi.org/10.1029/1999JD901161, 2000.

Ackerman, A. S., Kirkpatrick, M. P., Stevens, D. E., and Toon, O. B.: The impact of humidity above stratiform clouds on indirect aerosol climate forcing, Nature, 432, 1014-1017, https://doi.org/10.1038/nature03174, 2004.

Albrecht, B. A.: Aerosols, Cloud Microphysics, and Fractional Cloudiness, Science, 245, 1227-1230, https://doi.org/10.1126/science.245.4923.1227, 1989.

Bechtold, P., Köhler, M., Jung, T., Doblas-Reyes, F., Leutbecher, M., Rodwell, M. J., Vitart, F., and Balsamo, G.: Advances in simulating atmospheric variability with the ECMWF model: From synoptic to decadal time-scales, Quarterly Journal of the Royal Meteorological Society, 134, 1337-1351, https://doi.org/10.1002/qj.289, 2008.

Bellouin, N., Quaas, J., Gryspeerdt, E., Kinne, S., Stier, P., Watson-Parris, D., Boucher, O., Carslaw, K. S., Christensen, M., Daniau, A. L., Dufresne, J. L., Feingold, G., Fiedler, S., Forster, P., Gettelman, A., Haywood, J. M., Lohmann, U., Malavelle, F., Mauritsen, T., McCoy, D. T., Myhre, G., Mülmenstädt, J., Neubauer, D., Possner, A., Rugenstein, M., Sato, Y., Schulz, M., Schwartz, S. E., Sourdeval, O., Storelvmo, T., Toll, V., Winker, D., and Stevens, B.: Bounding Global Aerosol Radiative Forcing of Climate Change, Reviews of Geophysics, 58, 1-45, https://doi.org/10.1029/2019RG000660, 2020.

Bodas-Salcedo, A., Webb, M. J., Bony, S., Chepfer, H., Dufresne, J.-L., Klein, S. A., Zhang, Y., Marchand, R., Haynes, J. M., Pincus, R., and John, V. O.: COSP: Satellite simulation software for model assessment, Bulletin of the American Meteorological Society, 92, 1023-1043, https://doi.org/10.1175/2011BAMS2856.1, 2011.

Brenguier, J. L., Burnet, F., and Geoffroy, O.: Cloud optical thickness and liquid water path-does the k coefficient vary with droplet concentration?, Atmospheric Chemistry and Physics, 11, 9771-9786, https://doi.org/10.5194/acp-11-9771-2011, 2011.

Christensen, M., Gettelman, A., Cermak, J., Dagan, G., Diamond, M., Douglas, A., Feingold, G., Glassmeier, F., Goren, T., Grosvenor, D., Gryspeerdt, E., Kahn, R., Li, Z., Ma, P.-L., Malavelle, F., McCoy, I., McCoy, D., McFarquhar, G., Mülmenstädt, J., Pal, S., Possner, A., Povey, A., Quaas, J., Rosenfeld, D., Schmidt, A., Schrödner, R., Sorooshian, A., Stier, P., Toll, V., Watson-Parris, D., Wood, R., Yang, M., and Yuan, T.: Opportunistic Experiments to Constrain Aerosol Effective Radiative Forcing, Atmospheric Chemistry and Physics, pp. 1-60, https://doi.org/10.5194/acp-2021-559, 2021.

Cole-Dai, J.: Volcanoes and climate, Wiley Interdisciplinary Reviews: Climate Change, 1, 824-839, https://doi.org/10.1002/wcc.76, 2010. Costa-Surós, M., Sourdeval, O., Acquistapace, C., Baars, H., Carbajal Henken, C., Genz, C., Hesemann, J., Jimenez, C., König, M., Kretzschmar, J., Madenach, N., Meyer, C. I., Schrödner, R., Seifert, P., Senf, F., Brueck, M., Cioni, G., Frederik Engels, J., Fieg, K., Gorges, K., Heinze, R., Kumar Siligam, P., Burkhardt, U., Crewell, S., Hoose, C., Seifert, A., Tegen, I., and Quaas, J.: Detection and attribution of aerosol-cloud interactions in large-domain large-eddy simulations with the ICOsahedral Non-hydrostatic model, Atmospheric Chemistry and Physics, 20, 5657-5678, https://doi.org/10.5194/acp-20-5657-2020, 2020.

Fioletov, V., McLinden, C., Griffin, D., Theys, N., Loyola, D., Hedelt, P., Krotkov, N., and Li, C.: Anthropogenic and volcanic point source SOlt;subgt;2lt;/subgt; emissions derived from TROPOMI on board Sentinel-5 Precursor: first results, Atmospheric Chemistry and Physics, 20, 5591-5607, https://doi.org/10.5194/acp-20-5591-2020, 2020.

Ghan, S. J., Abdul-Razzak, H., Nenes, A., Ming, Y., Liu, X., Ovchinnikov, M., Shipway, B., Meskhidze, N., Xu, J., and Shi, X.: Droplet nucleation: Physically-based parameterizations and comparative evaluation, Journal of Advances in Modeling Earth Systems, 3, https://doi.org/10.1029/2011ms000074, 2011. 
Giorgetta, M. A., Brokopf, R., Crueger, T., Esch, M., Fiedler, S., Helmert, J., Hohenegger, C., Kornblueh, L., Köhler, M., Manzini, E., Mauritsen, T., Nam, C., Raddatz, T., Rast, S., Reinert, D., Sakradzija, M., Schmidt, H., Schneck, R., Schnur, R., Silvers, L., Wan, H., Zängl, G., and Stevens, B.: ICON-A, the Atmosphere Component of the ICON Earth System Model: I. Model Description, Journal of Advances in Modeling Earth Systems, 10, 1613-1637, https://doi.org/10.1029/2017MS001242, 2018.

Grosvenor, D. P., Sourdeval, O., Zuidema, P., Ackerman, A., Alexandrov, M. D., Bennartz, R., Boers, R., Cairns, B., Chiu, J. C., Christensen, M., Deneke, H., Diamond, M., Feingold, G., Fridlind, A., Hünerbein, A., Knist, C., Kollias, P., Marshak, A., McCoy, D., Merk, D., Painemal, D., Rausch, J., Rosenfeld, D., Russchenberg, H., Seifert, P., Sinclair, K., Stier, P., van Diedenhoven, B., Wendisch, M., Werner, F., Wood, R., Zhang, Z., and Quaas, J.: Remote Sensing of Droplet Number Concentration in Warm Clouds: A Review of the Current State of Knowledge and Perspectives, Reviews of Geophysics, 56, 409-453, https://doi.org/10.1029/2017RG000593, 2018.

Gryspeerdt, E., Goren, T., Sourdeval, O., Quaas, J., Mülmenstädt, J., Dipu, S., Unglaub, C., Gettelman, A., and Christensen, M.: Constraining the aerosol influence on cloud liquid water path, Atmospheric Chemistry and Physics, 19, 5331-5347, https://doi.org/10.5194/acp-195331-2019, 2019.

Hande, L. B., Engler, C., Hoose, C., and Tegen, I.: Parameterizing cloud condensation nuclei concentrations during HOPE, Atmospheric Chemistry and Physics, 16, 12 059-12 079, https://doi.org/10.5194/acp-16-12059-2016, 2016.

Heinze, R., Dipankar, A., Henken, C. C., Moseley, C., Sourdeval, O., Trömel, S., Xie, X., Adamidis, P., Ament, F., Baars, H., Barthlott, C., Behrendt, A., Blahak, U., Bley, S., Brdar, S., Brueck, M., Crewell, S., Deneke, H., Di Girolamo, P., Evaristo, R., Fischer, J., Frank, C., Friederichs, P., Göcke, T., Gorges, K., Hande, L., Hanke, M., Hansen, A., Hege, H., Hoose, C., Jahns, T., Kalthoff, N., Klocke, D., Kneifel, S., Knippertz, P., Kuhn, A., van Laar, T., Macke, A., Maurer, V., Mayer, B., Meyer, C. I., Muppa, S. K., Neggers, R. A. J., Orlandi, E., Pantillon, F., Pospichal, B., Röber, N., Scheck, L., Seifert, A., Seifert, P., Senf, F., Siligam, P., Simmer, C., Steinke, S., Stevens, B., Wapler, K., Weniger, M., Wulfmeyer, V., Zängl, G., Zhang, D., and Quaas, J.: Large-eddy simulations over Germany using ICON: a comprehensive evaluation, Quarterly Journal of the Royal Meteorological Society, 143, 69-100, https://doi.org/10.1002/qj.2947, 2017.

Ialongo, I., Hakkarainen, J., Kivi, R., Anttila, P., Krotkov, N. A., Yang, K., Li, C., Tukiainen, S., Hassinen, S., and Tamminen, J.: Comparison of operational satellite SOlt;subgt;2lt;/subgt; products with ground-based observations in northern Finland during the Icelandic Holuhraun fissure eruption, Atmospheric Measurement Techniques, 8, 2279-2289, https://doi.org/10.5194/amt-8-2279-2015, 2015.

Ilyinskaya, E., Schmidt, A., Mather, T. A., Pope, F. D., Witham, C., Baxter, P., Jóhannsson, T., Pfeffer, M., Barsotti, S., Singh, A., Sanderson, P., Bergsson, B., McCormick Kilbride, B., Donovan, A., Peters, N., Oppenheimer, C., and Edmonds, M.: Understanding the environmental impacts of large fissure eruptions: Aerosol and gas emissions from the 2014-2015 Holuhraun eruption (Iceland), Earth and Planetary Science Letters, 472, 309-322, https://doi.org/10.1016/j.eps1.2017.05.025, 2017.

Inguaggiato, S., Diliberto, I. S., Federico, C., Paonita, A., and Vita, F.: Review of the evolution of geochemical monitoring, networks and methodologies applied to the volcanoes of the Aeolian Arc (Italy), Earth-Science Reviews, 176, 241-276, https://doi.org/10.1016/j.earscirev.2017.09.006, 2018.

Inness, A., Ades, M., Agustí-Panareda, A., Barré, J., Benedictow, A., Blechschmidt, A.-M., Dominguez, J. J., Engelen, R., Eskes, H., Flemming, J., Huijnen, V., Jones, L., Kipling, Z., Massart, S., Parrington, M., Peuch, V.-H., Razinger, M., Remy, S., Schulz, M., and Suttie, M.: The CAMS reanalysis of atmospheric composition, Atmospheric Chemistry and Physics, 19, 3515-3556, https://doi.org/10.5194/acp-193515-2019, 2019.

Khain, A. P., BenMoshe, N., and Pokrovsky, A.: Factors determining the impact of aerosols on surface precipitation from clouds: An attempt at classification, Journal of the Atmospheric Sciences, 65, 1721-1748, https://doi.org/10.1175/2007JAS2515.1, 2008. 
Klocke, D., Brueck, M., Hohenegger, C., and Stevens, B.: Rediscovery of the doldrums in storm-resolving simulations over the tropical Atlantic /704/106 /704/106/35 /704/106/35/823 perspective, Nature Geoscience, 10, 891-896, https://doi.org/10.1038/s41561-017-00054, 2017.

Köhler, H.: The nucleus in and the growth of hygroscopic droplets, Transactions of the Faraday Society, 32, 1152-1161, https://doi.org/10.1039/TF9363201152, 1936.

Kolzenburg, S., Giordano, D., Thordarson, T., Höskuldsson, A., and Dingwell, D. B.: The rheological evolution of the 2014/2015 eruption at Holuhraun, central Iceland, Bulletin of Volcanology, 79, https://doi.org/10.1007/s00445-017-1128-6, 2017.

Kretzschmar, J., Salzmann, M., Mülmenstädt, J., and Quaas, J.: Arctic clouds in ECHAM6 and their sensitivity to cloud microphysics and surface fluxes, Atmospheric Chemistry and Physics, 19, 10 571-10 589, https://doi.org/10.5194/acp-19-10571-2019, 2019.

Kretzschmar, J., Stapf, J., Klocke, D., Wendisch, M., and Quaas, J.: Employing airborne radiation and cloud microphysics observations to improve cloud representation in ICON at kilometer-scale resolution in the Arctic, Atmospheric Chemistry and Physics, 20, 13 145-13 165, https://doi.org/10.5194/acp-20-13145-2020, 2020.

Lai, R., Teng, S., Yi, B., Letu, H., Min, M., Tang, S., and Liu, C.: Comparison of cloud properties from Himawari-8 and FengYun-4A geostationary satellite radiometers with MODIS cloud retrievals, Remote Sensing, 11, https://doi.org/10.3390/rs11141703, 2019.

Levy, R. C., Mattoo, S., Munchak, L. A., Remer, L. A., Sayer, A. M., Patadia, F., and Hsu, N. C.: The Collection 6 MODIS aerosol products over land and ocean, Atmospheric Measurement Techniques, 6, 2989-3034, https://doi.org/10.5194/amt-6-2989-2013, 2013.

Liu, Y. and Daum, P. H.: Indirect warming effect from dispersion forcing, Nature, 419, 580-581, https://doi.org/10.1038/419580a, 2002.

Loeb, N. G., Manalo-Smith, N., Su, W., Shankar, M., and Thomas, S.: CERES top-of-atmosphere earth radiation budget climate data record: Accounting for in-orbit changes in instrument calibration, Remote Sensing, 8, https://doi.org/10.3390/rs8030182, 2016.

Luo, Y., Xu, K. M., Morrison, H., and McFarquhar, G.: Arctic mixed-phase clouds simulated by a cloud-resolving model: Comparison with ARM observations and sensitivity to microphysics parameterizations, Journal of the Atmospheric Sciences, 65, 1285-1303, https://doi.org/10.1175/2007JAS2467.1, 2008.

Malavelle, F. F., Haywood, J. M., Jones, A., Gettelman, A., Clarisse, L., Bauduin, S., Allan, R. P., Karset, I. H. H., Kristjánsson, J. E., Oreopoulos, L., Cho, N., Lee, D., Bellouin, N., Boucher, O., Grosvenor, D. P., Carslaw, K. S., Dhomse, S., Mann, G. W., Schmidt, A., Coe, H., Hartley, M. E., Dalvi, M., Hill, A. A., Johnson, B. T., Johnson, C. E., Knight, J. R., O’Connor, F. M., Stier, P., Myhre, G., Platnick, S., Stephens, G. L., Takahashi, H., and Thordarson, T.: Strong constraints on aerosol-cloud interactions from volcanic eruptions, Nature, 546, 485-491, https://doi.org/10.1038/nature22974, 2017.

Mather, T. A., Pyle, D. M., and Allen, A. G.: Volcanic source for fixed nitrogen in the early Earth's atmosphere, Geology, 32, 905-908, https://doi.org/10.1130/G20679.1, 2004.

McCoy, D. T., Bender, F. A., Grosvenor, D. P., Mohrmann, J. K., Hartmann, D. L., Wood, R., and Field, P. R.: Predicting decadal trends in cloud droplet number concentration using reanalysis and satellite data, Atmospheric Chemistry and Physics, 18, 2035-2047, https://doi.org/10.5194/acp-18-2035-2018, 2018.

Nakajima, T. and King, M. D.: Determination of the Optical Thickness and Effective Particle Radius of Clouds from Reflected Solar Radiation Measurements. Part I: Theory, Journal of the Atmospheric Sciences, 47, 1878-1893, https://doi.org/10.1175/15200469(1990)047<1878:DOTOTA>2.0.CO;2, 1990.

Pincus, R. and Baker, M. B.: Effect of precipitation on the albedo susceptibility of clouds in the marine boundary layer, Nature, 372, 250-252, https://doi.org/10.1038/372250a0, 1994. 
Pincus, R., Platnick, S., Ackerman, S. A., Hemler, R. S., and Patrick Hofmann, R. J.: Reconciling simulated and observed views of clouds: MODIS, ISCCP, and the limits of instrument simulators, Journal of Climate, 25, 4699-4720, https://doi.org/10.1175/JCLI-D-11-00267.1, 2012.

Platnick, S., Meyer, K. G., King, M. D., Wind, G., Amarasinghe, N., Marchant, B., Arnold, G. T., Zhang, Z., Hubanks, P. A., Holz, R. E., Yang, P., Ridgway, W. L., and Riedi, J.: The MODIS Cloud Optical and Microphysical Products: Collection 6 Updates and Examples from Terra and Aqua, IEEE Transactions on Geoscience and Remote Sensing, 55, 502-525, https://doi.org/10.1109/TGRS.2016.2610522, 2017.

Quaas, J., Boucher, O., and Lohmann, U.: Constraining the total aerosol indirect effect in the LMDZ and ECHAM4 GCMs using MODIS satellite data, Atmospheric Chemistry and Physics, 6, 947-955, https://doi.org/10.5194/acp-6-947-2006, 2006.

Robock, A.: A latitudinally dependent volcanic dust veil index, and its effect on climate simulations, Journal of Volcanology and Geothermal Research, 11, 67-80, https://doi.org/10.1016/0377-0273(81)90076-7, 1981.

Roh, W., Satoh, M., Hashino, T., Okamoto, H., and Seiki, T.: Evaluations of the thermodynamic phases of clouds in a cloud-systemresolving model using calipso and a satellite simulator over the southern ocean, Journal of the Atmospheric Sciences, 77, 3781-3801, https://doi.org/10.1175/JAS-D-19-0273.1, 2020.

Rose, W. I., Bluth, G. J. S., Schneider, D. J., Ernst, G. G. J., Riley, C. M., Henderson, L. J., and McGimsey, R. G.: Observations of Volcanic Clouds in Their First Few Days of Atmospheric Residence: The 1992 Eruptions of Crater Peak, Mount Spurr Volcano, Alaska, The Journal of Geology, 109, 677-694, https://doi.org/10.1086/323189, 2001.

Sahyoun, M., Freney, E., Brito, J., Duplissy, J., Gouhier, M., Colomb, A., Dupuy, R., Bourianne, T., Nowak, J. B., Yan, C., Petäjä, T., Kulmala, M., Schwarzenboeck, A., Planche, C., and Sellegri, K.: Evidence of New Particle Formation Within Etna and Stromboli Volcanic Plumes and Its Parameterization From Airborne In Situ Measurements, Journal of Geophysical Research: Atmospheres, 124, 5650-5668, https://doi.org/10.1029/2018JD028882, 2019.

Saponaro, G., Sporre, M. K., Neubauer, D., Kokkola, H., Kolmonen, P., Sogacheva, L., Arola, A., De Leeuw, G., Karset, I. H., Laaksonen, A., and Lohmann, U.: Evaluation of aerosol and cloud properties in three climate models using MODIS observations and its corresponding COSP simulator, as well as their application in aerosol-cloud interactions, Atmospheric Chemistry and Physics, 20, 1607-1626, https://doi.org/10.5194/acp-20-1607-2020, 2020.

Seifert, A. and Beheng, K. D.: A two-moment cloud microphysics parameterization for mixed-phase clouds. Part 1: Model description, Meteorology and Atmospheric Physics, 92, 45-66, https://doi.org/10.1007/s00703-005-0112-4, 2006.

Seifert, A., Köhler, C., and Beheng, K. D.: Aerosol-cloud-precipitation effects over Germany as simulated by a convective-scale numerical weather prediction model, Atmospheric Chemistry and Physics, 12, 709-725, https://doi.org/10.5194/acp-12-709-2012, 2012.

Small, J. D., Chuang, P. Y., Feingold, G., and Jiang, H.: Can aerosol decrease cloud lifetime?, Geophysical Research Letters, 36, 1-5, https://doi.org/10.1029/2009GL038888, 2009.

Stevens, B. and Feingold, G.: Untangling aerosol effects on clouds and precipitation in a buffered system, Nature, 461, 607-613, https://doi.org/10.1038/nature08281, 2009.

Stevens, B., Acquistapace, C., Hansen, A., Heinze, R., Klinger, C., Klocke, D., Rybka, H., Schubotz, W., Windmiller, J., Adamidis, P., Arka, I., Barlakas, V., Biercamp, J., Brueck, M., Brune, S., Buehler, S. A., Burkhardt, U., Cioni, G., Costa-Surós, M., Crewell, S., Crüger, T., Deneke, H., Friederichs, P., Henken, C. C., Hohenegger, C., Jacob, M., Jakub, F., Kalthoff, N., Köhler, M., van LAAR, T. W., Li, P., Löhnert, U., Macke, A., Madenach, N., Mayer, B., Nam, C., Naumann, A. K., Peters, K., Poll, S., Quaas, J., Röber, N., Rochetin, N., Scheck, L., Schemann, V., Schnitt, S., Seifert, A., Senf, F., Shapkalijevski, M., Simmer, C., Singh, S., Sourdeval, O., Spickermann, D., 

for simulating clouds and precipitation, Journal of the Meteorological Society of Japan, 98, 395-435, https://doi.org/10.2151/jmsj.2020$021,2020$.

Su, W., Corbett, J., Eitzen, Z., and Liang, L.: Next-generation angular distribution models for top-of-atmosphere radiative flux calculation from CERES instruments: Methodology, Atmospheric Measurement Techniques, 8, 611-632, https://doi.org/10.5194/amt-8-611-2015, 2015.

Tiedtke, M.: A Comprehensive Mass Flux Scheme for Cumulus Parameterization in Large-Scale Models, Monthly Weather Review, 117, 1779-1800, https://doi.org/10.1175/1520-0493(1989)117<1779:ACMFSF>2.0.CO;2, 1989.

Toll, V., Christensen, M., Gassó, S., and Bellouin, N.: Volcano and Ship Tracks Indicate Excessive Aerosol-Induced Cloud Water Increases in a Climate Model, Geophysical Research Letters, 44, 12,492-12,500, https://doi.org/10.1002/2017GL075280, 2017.

445 Twomey, S.: The nuclei of natural cloud formation part II: The supersaturation in natural clouds and the variation of cloud droplet concentration, Geofisica Pura e Applicata, 43, 243-249, https://doi.org/10.1007/BF01993560, 1959.

Twomey, S.: Pollution and the planetary albedo, Atmospheric Environment (1967), 8, 1251-1256, https://doi.org/10.1016/00046981(74)90004-3, 1974.

Webb, M. J., Andrews, T., Bodas-Salcedo, A., Bony, S., Bretherton, C. S., Chadwick, R., Chepfer, H., Douville, H., Good, P., Kay, J. E., Klein, S. A., Marchand, R., Medeiros, B., Pier Siebesma, A., Skinner, C. B., Stevens, B., Tselioudis, G., Tsushima, Y., and Watanabe, M.: The Cloud Feedback Model Intercomparison Project (CFMIP) contribution to CMIP6, Geoscientific Model Development, 10, 359-384, https://doi.org/10.5194/gmd-10-359-2017, 2017.

West, R. E., Stier, P., Jones, A., Johnson, C. E., Mann, G. W., Bellouin, N., Partridge, D. G., and Kipling, Z.: The importance of vertical velocity variability for estimates of the indirect aerosol effects, Atmospheric Chemistry and Physics, 14, 6369-6393, https://doi.org/10.5194/acp-14-6369-2014, 2014.

Xue, H., Feingold, G., and Stevens, B.: Aerosol effects on clouds, precipitation, and the organization of shallow cumulus convection, Journal of the Atmospheric Sciences, 65, 392-406, https://doi.org/10.1175/2007JAS2428.1, 2008.

Yang, K.: OMPS-NPP L2 NM Sulfur Dioxide (SO2) Total and Tropospheric Column swath orbital V2, Greenbelt, MD, USA, GES DISCGoddard Earth Sciences Data and Information Services Center [data set], 2017.

460 Zängl, G., Reinert, D., Rípodas, P., and Baldauf, M.: The ICON (ICOsahedral Non-hydrostatic) modelling framework of DWD and MPI-M: Description of the non-hydrostatic dynamical core, Quarterly Journal of the Royal Meteorological Society, 141, 563-579, https://doi.org/10.1002/qj.2378, 2015. 